\title{
PERBANDINGAN METODE GAUSSIAN PARTICLE SWARM OPTIMIZATION (GPSO) DAN LAGRANGE MULTIPLIER PADA MASALAH ECONOMIC DISPATCH
}

\author{
Siti Komsiyah \\ Mathematics \& Statistics Department, School of Computer Science, Binus University \\ Jln. K.H. Syahdan No. 9, Palmerah, Jakarta Barat 11480 \\ citie_math@binus.ac.id
}

\begin{abstract}
On electric power system operation, economic planning problem is one variable to take into account due to operational cost efficiency. Economic Dispatch problem of electric power generation is discussed in this study to manage the output division on several units based on the the required load demand, with minimum operating cost yet is able to satisfy equality and inequality constraint of all units and system. In this study the Economic Dispatch problem which has non linear cost function is solved using swarm intelligent method is Gaussian Particle Swarm Optimization (GPSO) and Lagrange Multiplier. GPSO is a population-based stochastic algorithms which their moving is inspired by swarm intelligent and probabilities theories. To analize its accuracy, the Economic Dispatch solution by GPSO method is compared with Lagrange Multiplier method. From the test result it is proved that GPSO method gives economic planning calculation better than Lagrange Multiplier does.
\end{abstract}

Keywords: power system, load demand, economic dispatch, Gaussian Particle Swarm Optimization (GPSO), Lagrange Multiplier

\begin{abstract}
ABSTRAK
Dalam pengoperasian sistem tenaga listrik (power system), masalah perencanaan yang ekonomis merupakan salah satu parameter yang harus diperhitungkan untuk penghematan biaya operasional. Masalah Economic Dispatch pada pembangkitan energi listrik dibahas pada penelitian ini untuk mengatur pembagian output pada sejumlah unit pembangkit sesuai beban yang diminta (load demand), dengan biaya operasional minimum tapi tetap memenuhi persamaan dan pertidaksamaan kendala pada semua unit dan sistem. Dalam penelitian ini, permasalahan Economic Dispatch yang mempunyai fungsi biaya non linear diselesaikan dengan metode swarm intelligent yaitu Gaussian Particle Swarm Optimization (GPSO) dan Lagrange Multiplier. GPSO adalah algoritma stokastik berdasarkan populasi yang geraknya diinspirasi oleh swarm intelligent dan teori probabilitas. Untuk menganalisis keakuratannya, solusi Economic Dispatch dengan metode GPSO akan dibandingkan dengan metode Lagrange Multiplier. Hasil uji coba penelitian ini memberikan perhitungan perencanaan ekonomis yang lebih baik menggunakan metode GPSO daripada Lagrange Multiplier.
\end{abstract}

Kata kunci: power system, load demand, perencanaan ekonomis, Gaussian Particle Swarm Optimization (GPSO), Lagrange Multiplier 


\section{PENDAHULUAN}

Penelitian ini membahas permasalahan economic power dispatching, yaitu pengoptimalan pembagian daya pada unit pembangkit dengan operasi beban tertentu sehingga perhitungan ekonomis menjadi prioritas atau nilai yang harus diperhitungkan untuk memperoleh keuntungan terhadap modal yang diinfestasikan. Efisiensi terhadap penggunaan bahan bakar yang optimal akan memperkecil biaya produksi bagi perusahaan penyalur daya listrik. Dalam pengoperasian sistem tenaga listrik selalu dilakukan pembagian pembebanan pada unit pembangkit yang akan mensuplai beban. Hal ini sangat berkaitan dengan proses minimalisasi biaya produksi daya listrik dan rugi-rugi daya yang hilang pada saluran transmisi. Namun, pada penelitian ini rugi-rugi daya pada saluran transmisi tidak diperhitungkan. Suatu power system pada umumnya dibagi menjadi tiga bagian, yaitu power generation, power transmission, dan power dispatching. Pada power system, pembangkitan dengan energi panas (berdasarkan teknologi yang berbeda seperti pembakaran batubara, nuklir, siklus kombinasi gas, gas turbin) dan pembangkit listrik tenaga air akan didistribusikan ke berbagai stasiun pembangkit melalui transmission line bertegangan tinggi. Oleh karena itu, sebelum berakhir pada konsumen, energi listrik dikonversi kedalam tingkat tegangan yang lebih rendah dan didistribusikan ke rumah-rumah, kota, pusat perbelanjaan, pabrik-pabrik dan lain sebagainya melalui jaringan distribusi energi listrik dan stasiun pembangkit (Wood \& Wollenberg, 1996).

Tujuan penelitian dengan masalah economic dispatch adalah untuk optimisasi matematika dalam operasi power system yang bertujuan untuk menentukan pengaturan pembangkitan daya listrik terbaik/optimal pada sejumlah unit pembangkit sehingga dapat memenuhi kebutuhan beban pada sistem dengan biaya produksi minimum (El-Ela et al, 2007; Park et al, 2006; Panigrahi et al, 2008; Zhao dan Cao, 2005).

Dalam perhitungan masalah economic dispatch telah banyak digunakan pendekatan konvensional seperti metode Gradient, metode Iterasi Lambda, metode Newton, algoritma Linear Programming, algoritma Dynamic Programming dan lain sebagainya (Wood \& Wollenberg, 1996). Metode konvensional dapat menemukan good solution dalam waktu yang cepat tetapi dengan pemilihan inisialisasi nilai awal (lambda) yang tidak mudah dan kurang efisien serta metode tersebut hanya dapat diaplikasikan pada masalah sederhana dalam skala kecil. Metode optimasi heuristik pun telah banyak diaplikasikan untuk menyelesaikan permasalahan economic dispatch antara lain Algoritma Genetika (GA) (Laoufi et al, 2006), Tabu Search (TS) (Ongsakul et al., 2004), Evolutionary Programming (EP) (Aziz et al, 2006), Ant Colony Optimization (ACO) (Slimani \& Bouktir, 2007), dan Particle Swarm Optimization (PSO). Sedangkan metode jaringan syaraf tiruan yang telah digunakan diantaranya adalah Simulated Annealing (SA) (Wong dan Chung, 1993), dan Hopfield Network (HN) (Dieu \& Ongsakul, 2007). Metode tersebut dapat digunakan untuk permasalahan yang kompleks, akan tetapi masih dihasilkan laju konvergen yang lambat untuk mendekati solusi optimal. Oleh karena itu masih diperlukan improvement untuk mendapatkan solusi yang lebih baik. Dari beberapa pertimbangan terhadap kelebihan dan kekurangan dari masing-masing metode tersebut maka dalam penelitian ini akan dibandingkan metode Lagrange Multiplier dengan metode Gaussian Particle Swarm Optimization (GPSO) untuk mencari solusi dari permasalahan economic dispatch dan kemudian akan dilakukan analisis dan uji hipotesa dari keakuratannya.

\section{METODE}

Pada sub bab ini dipaparkan langkah-langkah untuk membahas permasalahan dalam penelitian. Pada bab ini juga dijelaskan bahan dan software yang digunakan dalam membantu penyelesaian permasalahan. 


\section{Bahan Penelitian}

Data yang digunakan dalam penelitian ini adalah data sistem kelistrikan area IV Jawa-Bali (Wahyono, 2000) sebagai berikut: (1) data kapasitas pembangkit termal; (2) data input output pembangkit termal; (3) data pembebanan maksimum dan minimum pembangkit; (4) harga bahan bakar yang digunakan pada pembangkit termal.

\section{Software yang Digunakan}

Pada penelitian ini, software yang digunakan untuk melakukan simulasi adalah MATLAB 6.5. Simulasi diimplementasikan pada Notebook dengan spesifikasi Processor Intel Dual-Core $2.0 \mathrm{GHz}$, memori utama sebesar 512 MB dan menggunakan sistem Operasi Windows XP.

\section{Landasan Teori}

\section{Biaya Operasional Pembangkit Termal}

Biaya operasi dari suatu sistem tenaga listrik merupakan biaya terbesar dalam pengoperasian suatu perusahaan listrik. Biaya yang dikeluarkan tersebut ditentukan oleh biaya investasi dan biaya operasi atau biaya produksi. Besar biaya investasi tidak tergantung pada besar daya keluaran pembangkit tetapi bergantung pada besar kapasitas daya terpasang pembangkit. Biaya investasi meliputi biaya pembangunan pusat pembangkit, jaringan transmisi dan distribusi serta peralatan sistem lainnya, sedangkan biaya operasi atau biaya produksi merupakan semua biaya yang dikeluarkan dalam pengoperasian suatu pembangkit. Untuk sistem yang sudah ada (telah beroperasi) biaya investasi telah tertentu besarnya.

Dari hal tersebut, pengoperasian sistem tenaga listrik perlu mengacu pada suatu manajemen operasi yang baik terutama karena melibatkan biaya operasi yang terbesar. Manajemen operasi sistem tenaga listrik yang baik harus mampu menyediakan tenaga listrik seekonomis mungkin dengan tetap memperhatikan mutu dan keandalan. Perhitungan yang ekonomis merupakan proses pembagian beban total ke masing-masing pusat pembangkitnya, sehingga total biaya pembangkitan dapat ditekan seminimal mungkin. Meminimumkan biaya operasi pembangkitan adalah merupakan optimisasi, sehingga optimisasi pembangkitan dapat didefinisikan sebagai suatu proses pembangkitan yang bertujuan untuk mengoptimalkan daya dan meminimumkan biaya pembangkitan (Wood \& Wollenberg, 1996).

\section{Unit Pembangkit Termal}

Pembangkit termal dikategorikan ke dalam pembangkit yang energi penggeraknya selain menggunakan energi air. Perhitungan optimal diterapkan pada pembangkit termal dimulai dengan pertimbangan harga bahan bakar termurah, yaitu pada pembangkit tenaga uap, tenaga gas dan tenaga diesel sehingga pembangkit tipe ini dioperasikan terlebih dahulu. Harga bahan bakar berubah secara tidak linear dengan bertambahnya daya output yang dihasilkan. Untuk menentukan kinerja dari pembangkit termal dapat dijelaskan melalui karakteristik input-output-nya (Wood \& Wollenberg, 1996).

\section{Karakteristik Ekonomis Pembangkit Termal}

Dalam analisis permasalahan yang berhubungan dengan pengoperasian suatu sistem daya, terdapat banyak parameter-parameter yang menjadi perhatian. Hal yang mendasar pada persoalan operasi ekonomis pembangkit adalah karakteristik input-output, karakteristik heat rate, dan karakteristik incremental heat rate dan fuel cost pada suatu unit pembangkit termal. 


\section{Karakteristik Input-Output Pembangkit Termal}

Karakteristik input output pembangkit termal adalah karakteristik yang menggambarkan hubungan antara besarnya input bahan bakar (kalori/jam atau Rupiah /jam) yang diberikan pada unit pembangkit sebagai fungsi dari output-nya(MW). Pada umumnya karakteristik input output pembangkit termal didekati dengan fungsi polinomial orde dua karena kenaikan harga bahan bakar yang tidak linear tergantung pada karakteristik unit pembangkit yaitu

dengan:

$$
H_{i}=\alpha_{i}+\beta_{i} P_{i}+\gamma_{i} P_{i}^{2}
$$

$H_{i} \quad=$ input bahan bakar pembangkit termal ke-i (Mkal/jam)

$P_{i} \quad=$ output pembangkit termal ke-i (MW)

$\alpha_{i}, \beta_{i}, \gamma_{i}=$ konstanta input-output pembangkit termal ke $-i$

Output listrik dari sistem pembangkit termal selain disalurkan melalui jaringan transmisi pada suatu sistem tenaga listrik juga digunakan pada sistem tenaga bantu (auxiliary power system) pada suatu pusat pembangkit. Unit turbin uap membutuhkan 2-6 \% dari output kotor untuk tenaga penggerak turbin (boiler), pompa, kipas, lampu dan sebagainya.

Untuk menggambarkan karakteristik input-output, input kotor direpresentasikan sebagai input total yang diukur dalam rupiah per jam dan output bersih pada suatu plant adalah output daya listrik dalam MW yang disediakan oleh sistem pembangkit tenaga listrik (Wood \& Wollenberg, 1996). Gambar 1 adalah karakteristik input-output unit pembangkit termal. Input dinyatakan dalam:

$\mathrm{H}=\mathrm{Mkal} / \mathrm{jam}$ (energi panas yang dibutuhkan), atau

$\mathrm{F}=$ Rupiah/jam ( total biaya bahan bakar)

Dan output dinyatakan dinyatakan dalam:

$\mathrm{P}=$ MW (daya).

Input, $\mathrm{F}(\mathrm{Rp} / \mathrm{jam})$ atau $\mathrm{H}(\mathrm{Mkal} / \mathrm{jam})$

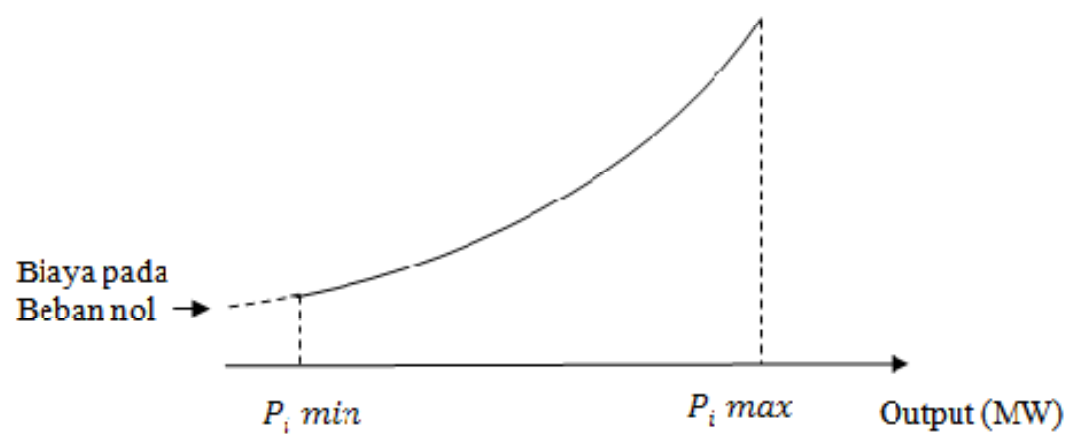

Gambar 1. Kurva karakteristik input-output pembangkit termal.

Membuat persamaan biaya operasional atau pembangkitan energi listrik menggunakan rumus: dengan:

$$
F_{i}=R_{i} x H_{i}
$$

$F_{i}=$ persamaan biaya pembangkitan dalam $\mathrm{Rp} / \mathrm{jam}$

$R_{i}=$ harga bahan bakar dalam Rp/Mkal

$H_{i}=$ fungsi karakteristik input-output dalam Mkal/jam. 
Data karakteristik input-output biasanya diperoleh dari hasil perhitungan desain atau dari hasil pengukuran. Unit pembangkit termal mempunyai batas kritis operasi minimum dan maksimum, batas beban minimum umumnya disebabkan oleh kestabilan pembakaran dan masalah desain generator, sebagai contoh beberapa unit pembangkit termal tidak dapat beroperasi di bawah 30\% dari kapasitas desain pembangkit.(Wood \& Wollenberg, 1996).

\section{Karakteristik Heat Rate}

Karakteristik Heat Rate adalah karakteristik yang merupakan efisiensi dari mesin. Untuk pemakaian bahan bakar, karakteristik heat rate sebuah unit pembangkit merupakan input panas yang diberikan untuk menghasilkan energi Mkal/jam tiap mega watt output dari suatu unit pembangkit. Kurva dari karakteristik heat rate dapat dilihat pada Gambar 2 di bawah ini.

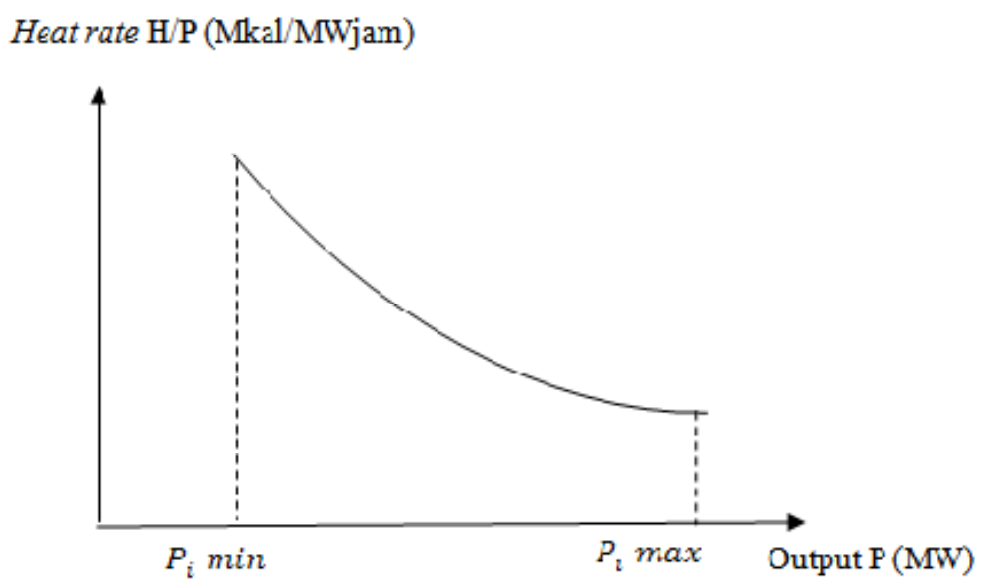

Gambar 2. Kurva karakteristik heat rate dari pembangkit termal.

\section{Karakteristik Incremental Heat Rate dan Incremental Fuel Cost}

Bentuk lain dari karakteristik pembangkit adalah karakteristik incremental heat rate, dan karakteristik incremental fuel cost. Karakteristik ini menunjukkan besarnya kenaikan input energi atau harga bahan bakar tiap ada perubahan pada Megawatt output unit pembangkit. Kurva dari karakteristik incremental heat rate atau incremental fuel cost dapat dilihat pada Gambar 3 di bawah ini, sedangkan persamaan incremental heat rate dan persamaan incremental fuel cost dapat dilihat pada persamaan (4.3) hingga (4.6).

$$
\begin{aligned}
& \text { Incremental heat rate }=\frac{\Delta H}{\Delta P}\left(\frac{\text { Mkal }}{\text { MWjam }}\right) \\
& \text { Incremental fuel cost }=\frac{\Delta F}{\Delta P}\left(\frac{\text { Rupiah }}{\text { MWjam }}\right)
\end{aligned}
$$

Jika nilai $\Delta$ sangat kecil, persaman diatas dapat dinyatakan sebagai berikut:

$$
\begin{aligned}
& \text { Incremental heat rate }=\frac{d H}{d P}\left(\frac{\text { Mkal }}{\text { MWjam }}\right) \\
& \text { Incremental fuel cost }=\frac{d F}{d P}\left(\frac{\text { Rupiah }}{\text { MWjam }}\right)
\end{aligned}
$$




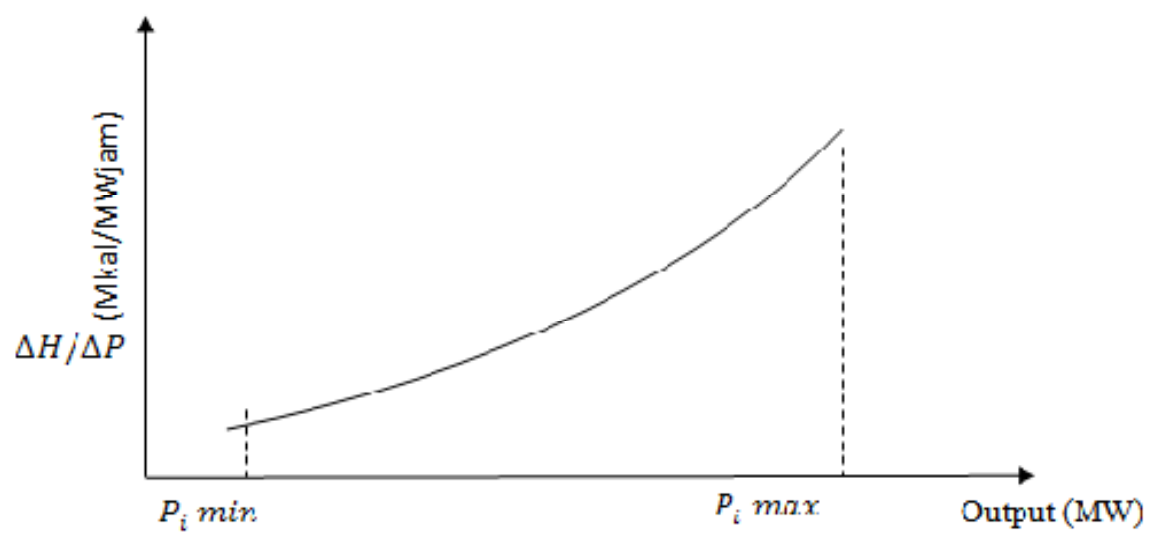

Gambar 3. Kurva karakteristik incremental heat rate (incremental fuel cost) pembangkit termal.

\section{Perumusan Masalah Economic Dispatch}

Fungsi obyektif dari masalah economic dispatch adalah

$$
f T=\sum_{i=1}^{N} F_{i}\left(P_{i}\right)
$$

dengan

$$
F_{i}\left(P_{i}\right)=a_{i}+b_{i} P_{i}+c_{i} P_{i}^{2}
$$

dimana:

$f \mathrm{~T} \quad=$ total biaya pembangkitan (Rupiah/jam).

$F_{i}\left(P_{i}\right) \quad=$ fungsi biaya input - Output dari generator i (Rupiah/jam)

$P_{i} \quad=$ output daya generator i (MW)

$N \quad=$ jumlah unit generator yang beroperasi

$i \quad=$ indeks dari banyaknya unit generator yang beroperasi

$a_{i}, b_{i}, c_{i} \quad=$ koefisien biaya bahan bakar (fuel cost) dari generator $\mathrm{i}$.

Satuan dari koefisien $a_{i}$ adalah Rp/jam, $b_{i}$ adalah Rp/MW.jam dan $c_{i}$ adalah Rp/MW' ${ }^{2}$ jam

(Coelho et al, 2008; Marsudi, 2006; Wood \& Wollenberg,1996 ).

Persamaan kendala pada permasalahan economic dispatch adalah:

$$
\sum_{i=1}^{N} P_{i}=P_{D}
$$

dengan:

$P_{D} \quad=$ total daya kebutuhan sistem (MW)

$P_{i} \quad=$ output daya generator $i(\mathrm{MW})$

$N \quad=$ jumlah unit generator yang beroperasi

$i \quad=$ indeks dari banyaknya unit generator yang beroperasi.

Pertidaksamaan kendala yang harus dipenuhi adalah:

$$
P_{i \min } \leq P_{i} \leq P_{i \max }
$$

dengan $P_{i \text { min }}$ dan $P_{i \text { max }}$ adalah output daya minimum dan maksimum generator $i$. 


\section{Tahap Penyelesaian dengan Metode Lagrange Multiplier}

Metode Lagrange Multiplier merupakan metode konvensional dengan menentukan persamaan Lagrange antara fungsi obyektif dan konstrain. Metode Lagrange Multiplier terdiri dari beberapa tahapan: (1) membaca data. Data-data yang harus diperhatikan adalah besarnya beban yang diminta, persamaan incremental cost, batas daya minimum dan batas daya maksimum yang akan dibangkitkan; (2) melakukan inisialisasi nilai parameter. Nilai awal parameter $\lambda$ dipilih dan ditentukan berdasarkan pengalaman perhitungan (trial and error); (3) menghitung masing-masing nilai dari $P_{1}, P_{2}, P_{3}, \ldots P_{N}$; (4) menghitung total daya yang dibangkitkan ( $\sum_{i=1}^{N} \grave{P}_{l}$ ); (5) mengevaluasi besarnya nilai persamaan kendala yaitu error selisih antara total daya yang dibangkitkan dan beban. Jika besarnya error memenuhi toleransi yang ditentukan (0.0001), selanjutnya menuju langkah 6 . Jika belum memenuhi toleransi, kembali ke langkah 3; (6) solusi $P_{1}, P_{2}, P_{3}, \ldots P_{N}$ telah didapatkan. Proses selesai. Tahapantahapan ini secara jelas ditunjukkan pada Gambar 4 (Marsudi, 2006).

\section{Tahap Penyelesaian dengan Algoritma GPSO}

Metode PSO yang digunakan dalam penelitian ini adalah PSO yang dikombinasikan dengan fungsi distribusi probabilitas Gaussian (GPSO) yang digunakan untuk membangkitka bilangan random. Distribusi Gaussian dapat memberikan konvergensi yang lebih cepat dalam pencarian lokal. Distribusi Gaussian digunakan untuk mengenerate bilangan random dalam interval [-1,1] pada koefisien akselerasi "cognitive part", koefisien akselerasi "social part" dan inisialisasi posisi dan kecepatan individu awal. Variabel-variabel yang digunakan bernilai integer dan bobot inertia bersifat dinamik dalam persamaan linear.

Prosedur implementasi dari GPSO dapat dijelaskan dalam tahap-tahap berikut: (1) inisialisasi. Inisialisasi swarm (populasi) dari partikel dengan posisi dan kecepatan secara random dalam $n$ dimensi ruang masalah menggunakan fungsi probabilitas berdistribusi Gaussian; (2) evaluasi. Evaluasi nilai fitness yaitu fungsi obyektif dari tiap-tiap partikel dalam swarm (populasi); (3) perbandingan pertama. Bandingkan masing-masing partikel fitnes dengan partikel pbest. Jika nilai sekarang lebih baik dari pbest, set nilai pbest sama dengan nilai sekarang dan lokasi pbest sama dengan lokasi sekarang dalam n- dimensi space; (4) perbandingan kedua. Bandingkan nilai fitness dengan populasi secara keseluruhan sebelum mencapai best. Jika nilai sekarang lebih baik dari gbest, ubah gbest ke nilai dan barisan indeks partikel sekarang; (5) update. Ubah kecepatan dan posisi partikel; (6) kriteria pemberhentian. Kembali ke tahap 2 sampai kriteria berhenti terpenuhi, biasanya syarat cukup nilai fitness terbaik atau banyaknya iterasi maksimum. Tahapan-tahapan GPSO secara jelas ditunjukkan pada Gambar 5.

\section{Tahap Perbandingan Hasil}

Tahap perbandingan hasil merupakan tahap membandingkan antara algoritma implementasi yang digunakan dilihat dari hasil output daya yang dibangkitkan, error dispatch, dan total biaya pembangkitan dengan data real sistem. Dengan membandingkan hasil yang diperoleh, dapat diketahui analisis performansi dari algoritma Lagrange Multiplier dan Gaussian Particle Swarm Optimization (GPSO).

\section{HASIL DAN PEMBAHASAN}

Persamaan biaya bahan bakar (fuel-cost) pada tiap unit pembangkit yang dioperasikan diperoleh dengan cara mengalikan persamaan karakteristik input output dengan harga bahan bakarnya, 
dalam hal ini harga bahan bakar yang telah ditetapkan per 31 Agustus 1998 sehingga diperoleh persamaan input output dalam rupiah per jam seperti pada Tabel 1.

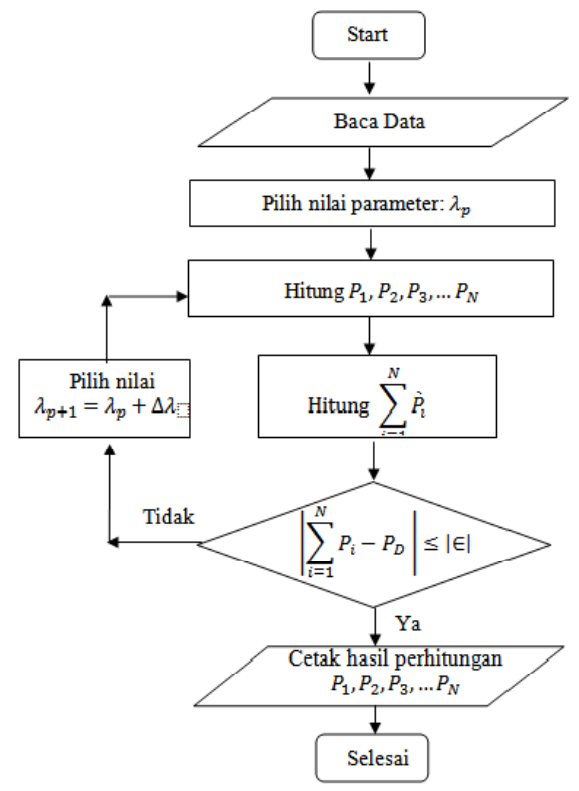

Gambar 4. Flowchart metode Lagrange Multiplier.

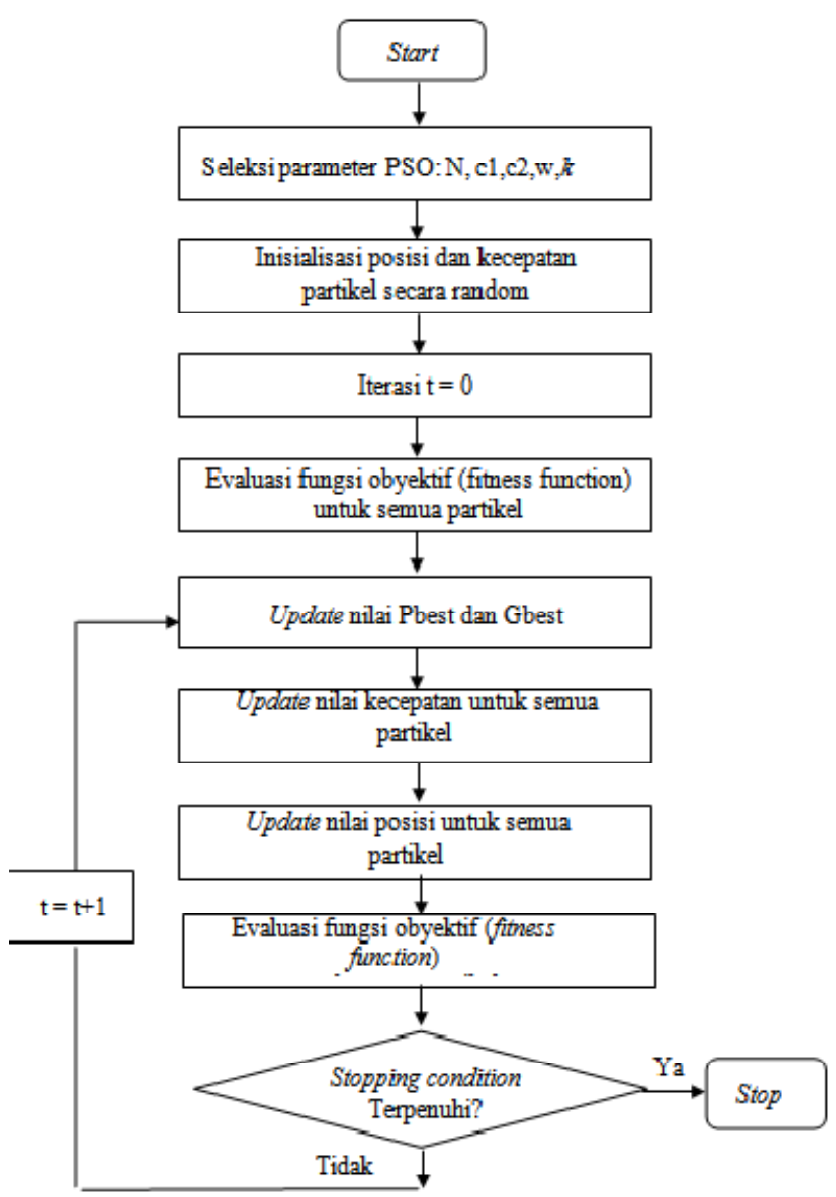

Gambar 5. Flow chart metode GPSO. 
Tabel 1

Persamaan Biaya Pembangkitan Unit-unit Pembangkit Termal pada Sistem Area IV Jawa-Bali

\begin{tabular}{cll}
\hline No. & \multicolumn{1}{c}{ Nama Pembangkit } & \multicolumn{1}{c}{ Persamaan Biaya Pembangkitan } \\
\hline 1 & PLTU Perak 3-4 & $\mathrm{F}=3.05 P^{2}+89780.85 P+645371.25$ \\
2 & PLTU Gresik 1-2 & $\mathrm{F}=507.72 P^{2}+205397.76 P+576981.6$ \\
3 & PLTU Gresik 3-4 & $\mathrm{F}=200.78 P^{2}+195212.5 P+23078.40$ \\
4 & PLTU Paiton 1-2 & $\mathrm{F}=263 P^{2}+55627.6 P+16530671.97$ \\
5 & PLTG Gilimanuk & $\mathrm{F}=81.38 P^{2}+92284.7 P+5046223.6$ \\
6 & PLTG Pesanggaran & $\mathrm{F}=6573.62 P^{2}+305711.06 P+8054565.84$ \\
7 & PLTG Gresik 1-5 & $\mathrm{F}=13355 P^{2}+116928.38 P+113581.52$ \\
8 & PLTD Pesanggaran & $\mathrm{F}=825.3 P^{2}+96382.38 P+5134237.44$ \\
9 & PLTGU Gresik & $\mathrm{F}=112.8 P^{2}+105555 P+70955.5$ \\
10 & PLTGU Grati & $\mathrm{F}=28.85 P^{2}+178376.8 P+14263605.12$ \\
\hline
\end{tabular}

(Sumber: P3B - PT PLN (Persero) Jawa-Bali Area IV, 1999)

Berikut ini adalah persamaan incremental fuel cost yang diperoleh dari proses diferensiasi pertama persamaan biaya pembangkitan dalam Tabel 2. Tabel 3 berikut ini memuat namanama pembangkit yang on atau beroperasi saat beban puncak tersebut beserta biaya operasi pembangkitannya sesuai dengan persamaan yang telah disebutkan. Dari tabel terlihat bahwa untuk beban puncak pada area IV pada tanggal 18 Agustus 1999, diperlukan biaya operasi sebesar Rp. 647.615.266,50 dimana biaya tersebut adalah biaya untuk mengoperasikan delapan unit pembangkit termis yang on atau beroperasi pada saat itu.

Tabel 2

Persamaan Incremental Fuel Cost (IFC) Pembangkit Termal Sistem Area IV Jawa-Bali

\begin{tabular}{rll}
\hline No. & \multicolumn{1}{c}{ Nama Pembangkit } & \multicolumn{1}{c}{ Persamaan Incremental fuel cost } \\
\hline 1 & PLTU Perak 3-4 & $\lambda=6,1 P+89780.85$ \\
2 & PLTU Gresik 1-2 & $\lambda=1015,44 P+205397.76$ \\
3 & PLTU Gresik 3-4 & $\lambda=401,56 P+195212.5$ \\
4 & PLTU Paiton 1-2 & $\lambda=526 P+55627.6$ \\
5 & PLTG Gilimanuk & $\lambda=162,76 P+92284.7$ \\
6 & PLTG Pesanggaran & $\lambda=13147,24 P+305711.06$ \\
7 & PLTG Gresik 1-5 & $\lambda=26710 P+116928.38$ \\
8 & PLTD Pesanggaran & $\lambda=1650,6 P+96382.38$ \\
9 & PLTGU Gresik & $\lambda=225,6 P+105555$ \\
10 & PLTGU Grati & $\lambda=57.7 P+178376.8$ \\
\hline
\end{tabular}

Tabel 3

Output Pembangkit yang Beroperasi Beserta Biaya Operasi

\begin{tabular}{clrr}
\hline No. & Nama Pembangkit & $\begin{array}{c}\text { Daya yang dibangkitkan } \\
\text { (MW) }\end{array}$ & $\begin{array}{c}\text { Biaya Operasi } \\
\text { (Rupiah/jam) }\end{array}$ \\
\hline 1 & PLTU Perak 3-4 & 130 & $35.859 .136,80$ \\
2 & PLTU Gresik 3-4 & 350 & $92.943 .003,40$ \\
3 & PLTU Paiton 1-2 & 801 & $140.714 .027,40$ \\
4 & PLTG Gilimanuk & 105 & $15.633 .331,60$ \\
5 & PLTG Pesanggaran & 47,8 & $8.461 .247,09$ \\
6 & PLTD Pesanggaran & 14.8 & $6.741 .470,37$ \\
7 & PLTGU Gresik & 1220 & $296.739 .575,50$ \\
8 & PLTGU Grati & 197 & $50.523 .474,37$ \\
\hline \multicolumn{2}{r}{ Total } & $\mathbf{2 8 6 5 , 6}$ & $\mathbf{6 4 7 . 6 1 5 . 2 6 6 , 5 0}$ \\
\hline
\end{tabular}

(Sumber: P3B - PT PLN (Persero) Jawa-Bali Area IV, 1999) 
Hasil perhitungan biaya bahan bakar masing-masing pembangkit dengan metode Lagrange Multiplier dan Gaussian Particle Swarm Optimization diuraikan pada Tabel 4 sebagai berikut:

Tabel 4

Perbandingan Hasil Perhitungan Program Economic Dispatch dengan Optimasi Metode Lagrange Multiplier dan GPSO

\begin{tabular}{clllll}
\hline No & Nama Pembangkit & $\begin{array}{c}\text { Metode Lagrange Multiplier } \\
\text { Daya yang } \\
\text { terbangkit } \\
\text { (MW) }\end{array}$ & $\begin{array}{l}\text { Biaya Operasi/ } \\
\text { Pembangkitan } \\
\text { (Rupiah / jam) }\end{array}$ & $\begin{array}{l}\text { Metode GPSO } \\
\text { Daya yang } \\
\text { terbangkit } \\
\text { (MW) }\end{array}$ & $\begin{array}{l}\text { Biaya Operasi/ } \\
\text { Pembangkitan } \\
\text { (Rupiah / jam) }\end{array}$ \\
\hline 1 & PLTU Perak 3-4 & 150,0000 & $14.181 .123,7500$ & 150,0000 & $14.181 .123,7500$ \\
2 & PLTU Gresik 3-4 & 233,1332 & $56.446 .187,1011$ & 216,1632 & $51.602 .581,6831$ \\
3 & PLTU Paiton 1-2 & 422,7734 & $87.056 .475,9335$ & 430,2957 & $89.162 .579,3755$ \\
4 & PLTG Gilimanuk & 145,0000 & $20.138 .519,0000$ & 144,9999 & $20.138 .519,4840$ \\
5 & PLTG Pesanggaran & 15,0000 & $14.119 .296,2400$ & 15,0000 & $14.119 .296,2400$ \\
6 & PLTD Pesanggaran & 75,0000 & $17.005 .228,4400$ & 75,0000 & $17.005 .228,4400$ \\
7 & PLTGU Gresik & 772,6934 & $148.980 .434,7615$ & 782,1412 & $151.634 .683,7839$ \\
8 & PLTGU Grati & $1.052,00$ & $233.844 .409,1200$ & $1.052,00$ & $233.844 .409,1200$ \\
\hline \multicolumn{7}{c}{ Total } & $\mathbf{2 . 8 6 5 , 6 0}$ & $\mathbf{5 9 1 . 7 7 1 . 6 7 4 , 3 4 6 1}$ & $\mathbf{2 . 8 6 5 , 6 0}$ & $\mathbf{5 9 1 . 6 8 8 . 4 2 1 , 8 6 6 5}$ \\
\hline \multicolumn{5}{c}{}
\end{tabular}

Beberapa kurva hasil simulasi pembangkit termal sistem Area IV Jawa-Bali menggunakan GPSO dapat dilihat pada Gambar 6. Tabel 5 berikut ini memuat perbandingan hasil konvergensi dari metode Lagrange Multiplier dan GPSO pada perhitungan economic dispatch sistem pembangkitan tenaga listrik area IV Jawa-Bali.

\section{Analisis Hasil Simulasi}

Analisis hasil simulasi berdasarkan solusi yang diperoleh dari dua metode tersebut pada dua studi kasus sistem tenaga listrik area IV Jawa-Bali. Metode GPSO yang merupakan teknik heuristik dengan kombinasi bilangan random berdistribusi Gaussian mampu mendapatkan solusi yang lebih baik dari metode Lagrange Multiplier. Dari beberapa uji coba atau running program ini, metode GPSO lebih cepat dalam pencarian minimum lokal atau lebih baik dalam mendapatkan konvergensi daripada metode PSO dasar. Perhitungan economic dispatch menggunakan metode GPSO memberikan akselerasi konvergensi yang berbeda disebabkan karena hasil random untuk posisi awal suatu partikel atau individu juga berbeda sehingga mengakibatkan globalbest yang berbeda yang dapat mempengaruhi akselerasi konvergensinya.

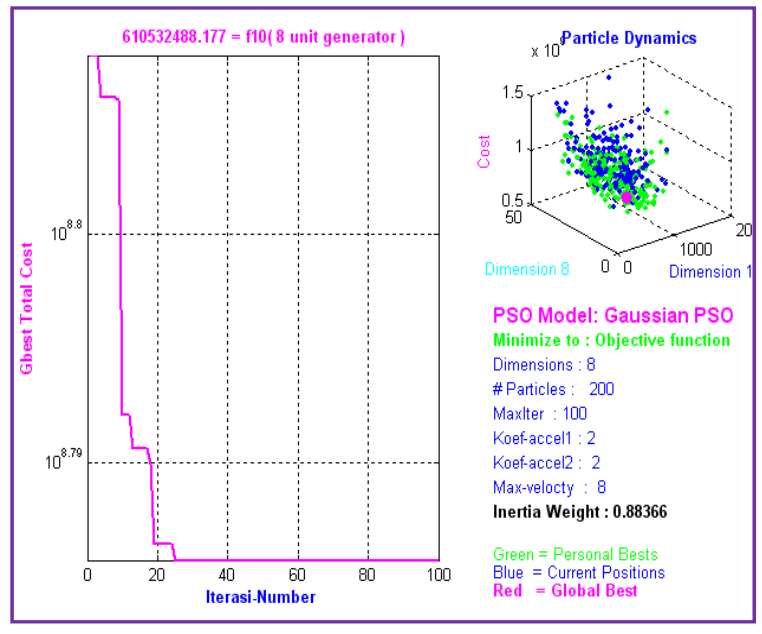

(A)

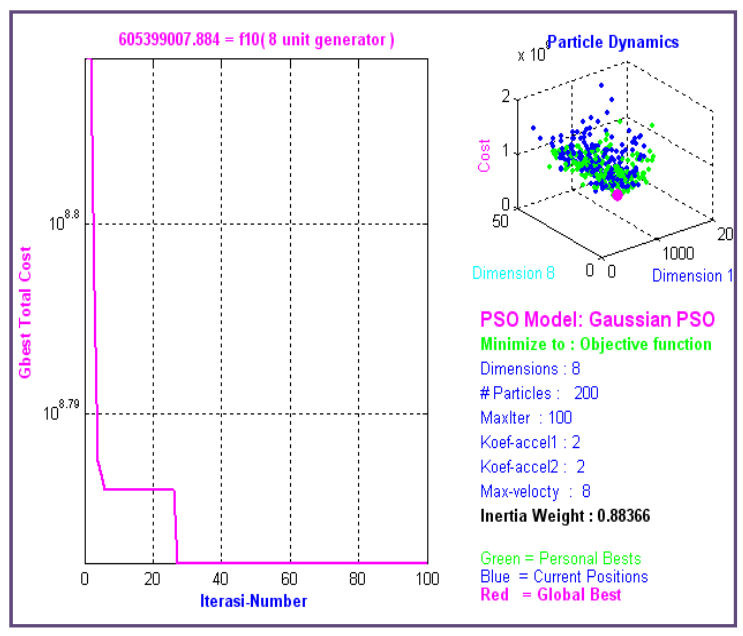

(B) 


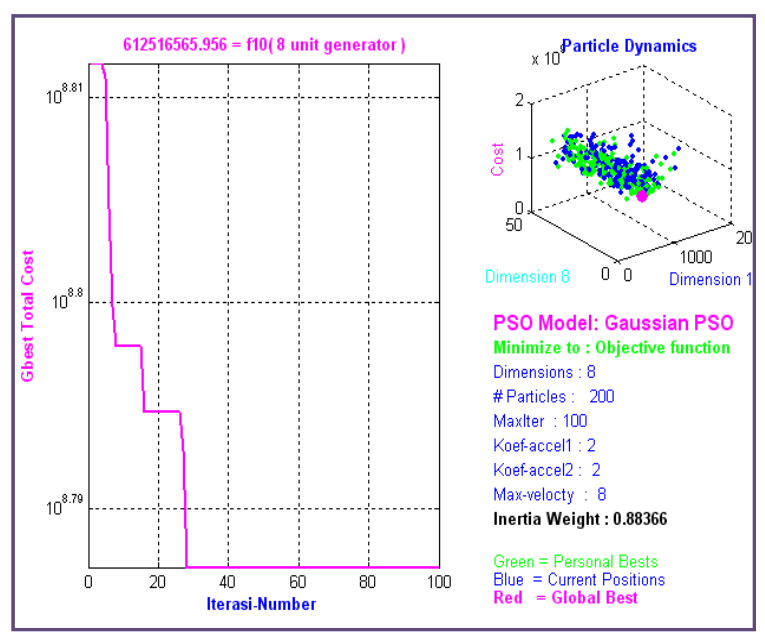

( C )

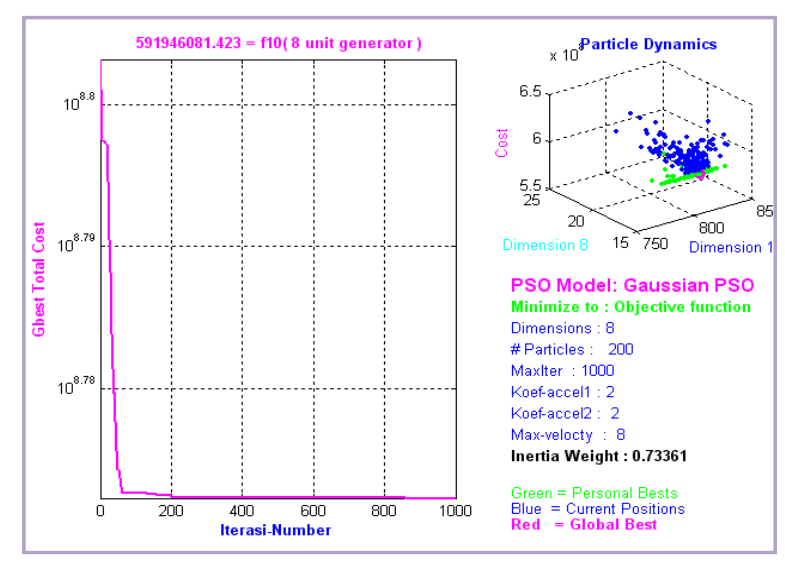

(E)

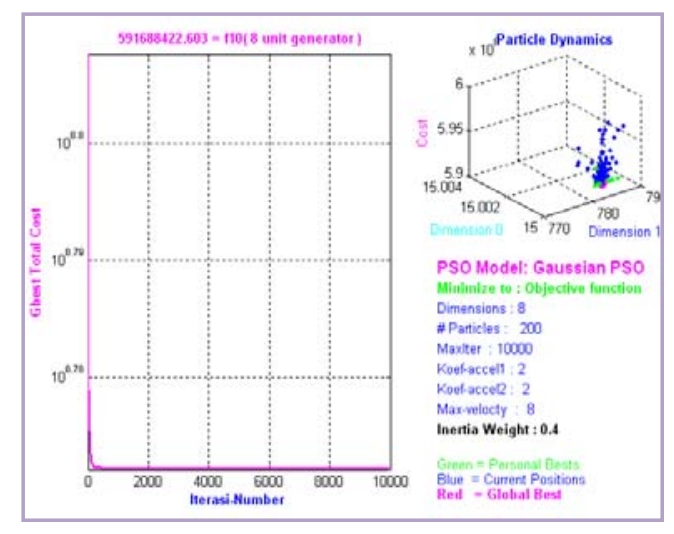

(G)

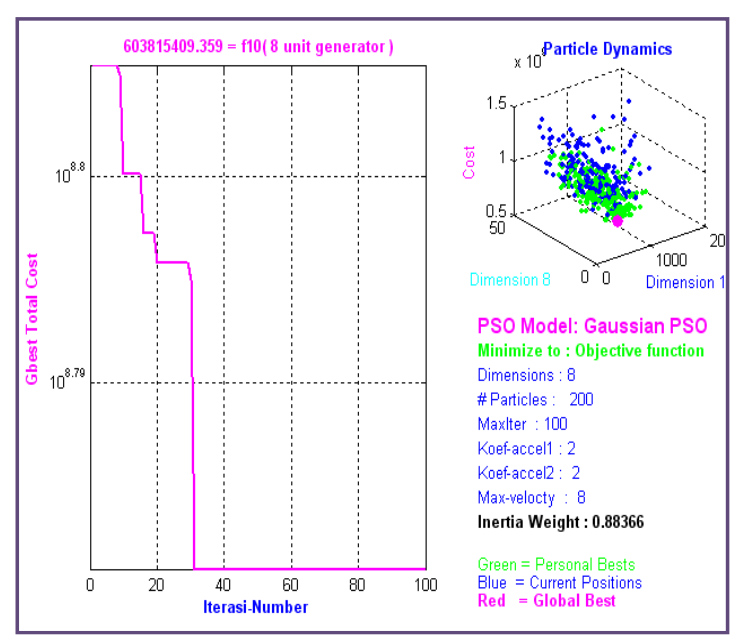

(D)

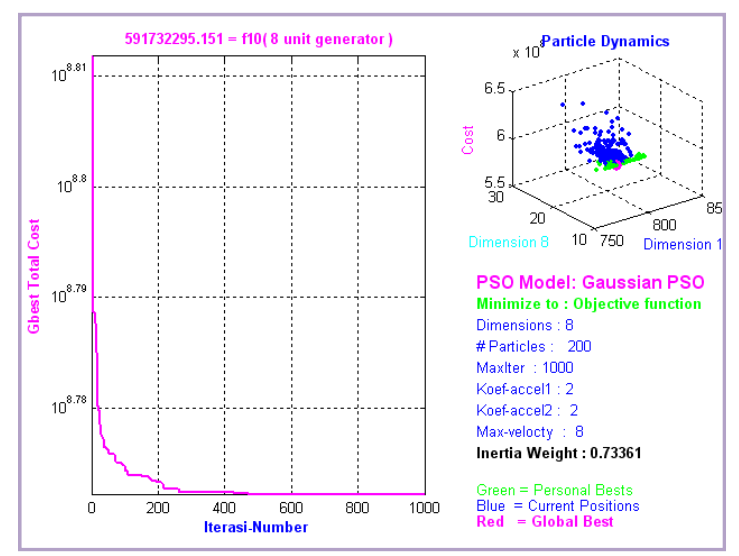

(F)

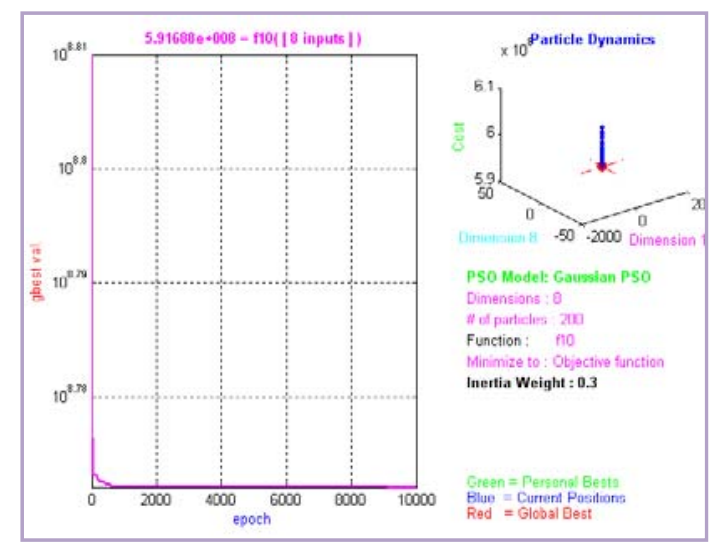

$(\mathrm{H})$

Gambar 6. (a),(b),(c),(d) Kurva hasil plot GPSO dengan 100 iterasi; (e),(f) Kurva plot GPSO untuk 1000 iterasi; (g),(h) Kurva plot GPSO untuk 10000 iterasi. 
Tabel 2

Hasil Konvergensi Studi Kasus Sistem Area IV dengan Beban = 2865,6 MW

\begin{tabular}{llc}
\hline \multicolumn{1}{c}{ Metode } & $\begin{array}{c}\text { Error dispatch } \\
\text { (MW) }\end{array}$ & \multicolumn{1}{c}{$\begin{array}{c}\text { Nilai fitness } \\
\text { (Rp/jam) }\end{array}$} \\
\hline Lagrange Multiplier & 0,00002871 & $591.771 .674,3461$ \\
GPSO & 0 & $591.688 .421,8665$ \\
\hline
\end{tabular}

Pada permasalahan economic dispatch, dalam hal ini untuk data pembangkitan sistem tenaga listrik area IV yang meliputi Jawa-Bali, hasil perhitungan yang diperoleh dengan metode Lagrange Multiplier dibandingkan data real sistem PLN (Persero) lebih optimum dengan penghematan biaya pembangkitan Rp 55.843.592,9317 per jam ( efisiensi biaya bahan bakar sebesar 9,4\% per jam). Untuk tingkat optimum penghematan biaya pembangkitan metode GPSO dibandingkan data pembangkitan PT PLN (persero) adalah 55.926.844,6355 per jam ( efisiensi biaya bahan bakar sebesar 9,5\% per jam). Sedangkan tingkat optimum penghematan biaya pembangkitan dari metode GPSO dibandingkan Lagrange Multiplier adalah Rp 83.252,4796 per jam ( efisiensi biaya bahan bakar sebesar 0,01\% per jam).

\section{PENUTUP}

Dengan mengimplementasikan metode Lagrange Multiplier dan GPSO untuk menghitung economic dispatch pada studi kasus data pembangkit termal sistem area IV Jawa-Bali ( Wahyono, 2000) dapat ditarik kesimpulan dari hasil simulasi sebagai berikut: (1) hasil simulasi yang dilakukan pada pembangkit termal sistem area IV Jawa-Bali dengan menggunakan GPSO memberikan performansi solusi yang lebih baik dibandingkan dengan metode Lagrange Multiplier dengan kombinasi daya yang dibangkitkan dapat memenuhi persamaan kendala dan pertidaksamaan kendala yang telah ditentukan; (2) pada sistem tenaga listrik pembangkit termal area IV Jawa-Bali, total biaya bahan bakar yang diperoleh dengan metode GPSO adalah sebesar Rp 591.688.421,8665 per jam sedangkan jika menggunakan metode Lagrange Multiplier sebesar Rp 591.771.674,3461 per jam. Tingkat optimum penghematan biaya pembangkitan dari metode GPSO dibandingkan Lagrange Multiplier adalah Rp 83.252,4796 per jam; (3) hasil simulasi menunjukkan bahwa dengan metode GPSO maupun Lagrange Multiplier diperoleh hasil yang lebih baik jika dibandingkan dengan real sistem di lapangan (PT PLN Persero).

Adapun prospek pengembangan dari hasil penelitian ini yang dapat digunakan sebagai kajian penelitian selanjutnya sebagai berikut: (1) metode Gaussian Particle Swarm Optimization (GPSO) yang digunakan pada penelitian ini masih memerlukan penelitian dan pengembangan lebih lanjut atau dapat juga dikombinasikan dengan metode lain untuk dapat lebih memperbaiki performansinya; (2) permasalahan economic dispatch pada penelitian ini dapat diperluas dengan penghitungan rugi-rugi daya transmisi, biaya pemeliharaan dan perbaikan mesin. Selain itu fungsi obyektif yang meminimumkan total biaya bahan bakar dapat dikombinasikan dengan fungsi obyektif yang meminimumkan emisi polutan dari proses pembangkitan.

\section{DAFTAR PUSTAKA}

Aziz, A. M. A., Musirin, J. I., dan Rahman, T. K. A. (2006). Solving Economic Dispatch Using Evolutionary Programming. First International Power and Energy Conference PECon, Putra Jaya, Malaysia, 144-149. 
Coelho, L.S dan Lee, C.S. (2008). Solving Economic Load Dispatch Problem in Power System. Journal of Electrical Power and Energy Systems, 30, 297-307.

Dieu, V. N. \& Ongsakul, W. (2007). Augmented Lagrange Hopfield Network for Large Scale Economic Dispatch. International Symposium on Electrical and Electronics Engineering, HCM City, Vietnam, 2, 19-26.

El-Ela, A.A.A. dan El-Sehiemy, R.A.A. (2007). Optimized Generation Costs Using Modified Particle Swarm Optimization Version. WSEAS Transactions on Power Systems, 2(10), 225-232.

Laoufi, A., Hazzab, A., \& Rahli, M. (2006). Economic Power Dispatch Using Fuzzy-Genetic Algorithm. International Jourrnal of Applied Engineering Research, 1(3), 409-426.

Marsudi, D. (2006). Operasi Sistem Tenaga Listrik, (edisi pertama). Yogyakarta: Graha Ilmu.

Ongsakul, W., Dechanupaprittha, S., \& Ngamroo, I. (2004). Parallel Tabu Search Algorithm for Constrained Economic Dispatch. IEE Proceeding of Generation, Transmission and Distribution, 151, 157-166.

Panigrahi, B. K., Pandi, V. R., \& Das, S. (2008). Adaptive Particle Swarm Optimization Approach for Static and Dynamic Economic Load Dispatch. Journal of Energy Conversion and Management, 49, 1407-1415.

Park, J. B, Shin, J.R., \& Jeong, Y.W. (2006). An Improved Particle Swarm Optimization for Economic Dispatch with Valve - Point Effect. International journal of Innovation in Energy System and Power, 1(1), 1-6.

Slimani, L, dan Bouktir, T. (2007). Economic Power Dispatch of Power System with Pollutan Control Using Multiobjective Ant Colony Optimization. International Journal of Computational Intelligence Research, 3(2), 145-153.

Wahyono, A.Y. (2000). Economic Dispatch Dengan Optimasi terhadap Daya Aktif dan Daya reaktif. Tugas Akhir. Institut Teknologi Sepuluh Nopember Surabaya, Surabaya.

Wong, K. P. \& Chung, C.C. (1993). Simulated Annealing Based Economic Dispatch Algorithm. IEE Proceeding of Generation, Transmission and Distribution, 140, 509-515.

Wood, A. J. \& Wollenberg, B. F (1996), Power Generation, Operation and Control, (2 ${ }^{\text {nd }}$ ed.). New York: John Wiley \& Sons.

Zhao, B. dan Cao, Y. J. (2005). Multiple Objective Particle Swarm Optimization Technique for Economic Load Dispatch. Journal of Zhejiang University SCIENCE, 6(5), 420-427. 